\title{
A CONTROLLED INVESTIGATION OF THE EFFECT OF DIET ON ACUTE NEPHRITIS
}

\author{
BY \\ R. S. ILLINGWORTH, M. G. PHILPOTT and JOHN RENDLE-SHORT \\ From the Department of Child Health, the University of Sheffield, and the \\ Children's Hospital Unit, the United Sheffield Hospitals \\ (RECEIVED FOR PLBLICATION JLLy 19, 1954)
}

A search of the literature concerning the role of diet in the treatment of acute nephritis revealed numerous expressions of opinion but very little evidence in the form of experimental work on which opinions can be based. The outstanding work is that of Addis (1948), who furnished conclusive evidence that in rats with experimental nephritis a high-protein diet was harmful and caused enlargement of the kidney, while life was prolonged by a low-protein diet. On the basis of this experimental evidence Addis recommended that protein should be considerably restricted in human beings suffering from nephritis, 'for decades if necessary' (Addis, 1940). He recommended that the diet should contain approximately $0.25 \mathrm{~g}$. of protein per $\mathrm{lb}$. per day, together with that quantity of protein which is lost in the urine. Farr and Smadel (1937) had previously shown that when rats with experimental nephritis were given a diet containing only $5 \%$ protein the kidney lesion healed rapidly and completely if the acute stage was survived, but if the diet contained $40 \%$ of protein the disease progressed and the rats died of chronic nephritis. Experimental nephritis in rats, however, is not necessarily comparable with acute nephritis in human beings, and the quantity of protein given in the high-protein diet (in some experiments up to $70 \%$ of the total food intake) was far greater than that which would ever be taken by man.

The only controlled experimental work on human beings which we were able to find was that of Schwensen (1935, 1937), Naeraa (1938) and Mortensen (1947). Schwensen treated six patients (children and adults) with a strict low-protein diet, and compared the duration of albuminuria and microscopic haematuria with that of 34 patients who were given a normal or high-protein diet. He found in the lowprotein diet group that albuminuria and haematuria disappeared in an average of 56 days and 73 days compared with 22 and 40 days respectively when a normal or high-protein diet was given. Unfor- tunately the number of cases in the low-protein group was small, and the method of controlling the study was unsatisfactory. It was not stated how patients were allocated to the different groups. Naeraa (1938) gave 10 patients alternating periods of high- and low-protein diets, and attempted to assess the result by Addis counts. He concluded that there was no increase in the excretion of red cells and casts during the phases of high-protein intake. Mortensen (1947) studied the effect of a high-protein and low-protein diet in $\mathbf{4 4}$ patients by the alternate case method. The duration of nephritis was the same in both groups, but albuminuria disappeared more rapidly in the group of patients which was given a high-protein diet.

Below is an account of a controlled investigation into the effect of protein intake on the healing of acute nephritis in human beings.

\section{Method of Study}

The diagnosis of acute nephritis was based on a history of symptoms of not more than three weeks' duration, without any history of a previous attack, together with the finding of haematuria, albuminuria, and granular and cellular casts in the urine. Cases of the nephrotic syndrome were excluded, and any case in which there was doubt as to whether the nephritis was acute or merely an exacerbation of a pre-existing nephritis was excluded. Most children showed oedema, hypertension and elevation of the blood urea, but it was not felt that these should be criteria for the diagnosis because they may subside before admission to hospital. All the children were between the ages of 2 and 14 years.

Once the diagnosis was established the treatment was chosen by the random sampling method. The groups were as follows:

Group A: Low-protein Diet. Twenty-two children were included in this group. The quantity of protein given was $0.25 \mathrm{~g}$. per lb. per day, together with 
the total daily amount of protein lost in the urine. On this basis the average protein intake was $0.3 \mathrm{~g}$. per lb. per day. The diet was continued after discharge from the hospital until two consecutive normal Addis counts had been obtained. The average duration of protein restriction in the 21 survivors was 293 days (standard deviation 232 days, Table 3). We did our best to ensure that the diet was adhered to, but it is never possible to be sure that departures from a strict diet are not made in the home. Only one surviving child (No. 18) maintained the diet for less than 100 days: he was discharged from hospital to a convalescent home, and it proved impossible to keep him on a lowprotein diet.

Group B: Normal Diet. Twenty children were given the ordinary ward diet. Analysis of the ward diet taken by 35 children at intervals throughout the period of study showed that the mean protein intake was $1 \cdot 23 \mathrm{~g}$. per lb. per day (standard deviation $0.55 \mathrm{~g}$.).

In all other respects the treatment in the two groups was identical. There was no constant policy regarding fluid restriction. The majority of children took what fluid they wanted. Children in both groups were kept in bed until the erythrocyte sedimentation rate was normal and there was no excess of red cells in the ordinary centrifuged specimen of urine.

The investigations in hospital included quantitative estimations of the amount of albumin in the urine, intake and output charts, daily blood pressure readings, a weekly erythrocyte sedimentation rate, and weekly blood urea estimations. An Addis count was performed when the centrifuged deposit of urine showed less than 3 R.B.C.s per high-power field. After discharge the children were seen monthly until the Addis count was normal, and the urine was examined for the specific gravity, the quantity of albumin and the deposit. The blood pressure was recorded, and the blood urea and erythrocyte sedimentation rates were estimated. Patients were re-admitted for Addis counts and renal function tests (water concentration and dilution, and urea clearance) at intervals until the nephritis was regarded as 'healed'. In all, 135 Addis counts were performed, all by one member of the team (M.G.P.). The patients were followed up at less frequent intervals after healing was considered to have taken place. In no case was the period of observation less than one year.

The nephritis was considered to be healed if all the following criteria were satisfied, and remained satisfied at subsequent examinations: (i) The blood pressure was normal. (ii) There were less than $10 \mathrm{mg}$. of albumin per $100 \mathrm{ml}$. in the urine. (iii) There were no granular or cellular casts in the centrifuged deposit of urine. (iv) There was less than 1 R.B.C. per high-power field in a centrifuged specimen. (v) The blood urea was less than $40 \mathrm{mg}$. per $100 \mathrm{ml}$. (vi) The Addis count showed an excretion of 500,000 R.B.C.s or less per 12 hours. (vii) The renal function tests were normal.

It was very difficult to apply such rigid criteria over a six-year period, and certain departures have been made. These are as follows:-

Isolated specimens of urine from five patients in Group A and seven patients in Group B were found to contain small amounts of albumin during the follow-up period. Table 1 shows the nature of the problem. In all these children the blood pressure and blood urea remained normal throughout the period of observation, the Addis count showed a normal number of red cells and there were no granular or cellular casts in the urine. The specific gravity was normal. Tests to determine whether the albumin was orthostatic were not carried out.

TABLE 1

OCCASIONAL ALBUMINURIA IN PATIENTS WITH 'HEALED' NEPHRITIS

\begin{tabular}{|c|c|c|c|c|c|}
\hline Group & Case No.* & $\begin{array}{l}\text { Duration of } \\
\text { Observation } \\
\text { (vears and months) }\end{array}$ & $\begin{array}{l}\text { Total Number of } \\
\text { Albumin-free Specimens } \\
\text { after Healing }\end{array}$ & $\begin{array}{l}\text { Number of } \\
\text { Albumin-containing } \\
\text { Specimenst }\end{array}$ & $\begin{array}{l}\text { Number of } \\
\text { Normal Specimens after } \\
\text { Last Abnormal One }\end{array}$ \\
\hline $\mathbf{A}$ & $\begin{array}{r}1 \\
9 \\
16 \\
17 \\
22\end{array}$ & $\begin{array}{l}4 \cdot 4 \\
2 \cdot 9 \\
3 \cdot 6 \\
1 \cdot 11 \\
1 \cdot 11\end{array}$ & $\begin{array}{l}8 \\
5 \\
6 \\
3 \\
1\end{array}$ & $\begin{array}{ll}1 & (90) \\
2 & (20,25) \\
1 & (75) \\
1 & (15) \\
1 & (80)\end{array}$ & $\begin{array}{l}7 \\
1 \\
2 \\
3 \\
1\end{array}$ \\
\hline B & $\begin{array}{l}25 \\
27 \\
29 \\
30 \\
31 \\
33 \\
39\end{array}$ & $\begin{array}{l}4 \cdot 2 \\
3 \cdot 0 \\
2 \cdot 0 \\
3 \cdot 3 \\
3 \cdot 1 \\
4 \cdot 5 \\
3 \cdot 8\end{array}$ & $\begin{array}{l}8 \\
6 \\
7 \\
5 \\
6 \\
6 \\
5\end{array}$ & $\begin{array}{ll}1 & (15) \\
1 & (30) \\
1 & (50) \\
3 & (20,100,65) \\
2 & (25,70) \\
1 & (40) \\
2 & (40,35)\end{array}$ & $\begin{array}{l}4 \\
4 \\
3 \\
1 \\
2 \\
2 \\
1\end{array}$ \\
\hline
\end{tabular}

- The case numbers were obtained by numbering the completed proformas after arranging the two groups in alphabetical order.

+ Quantity of albumin in $\mathrm{mg}$. $\%$ in brackets. 
It will be seen that in all cases subsequent specimens of urine were albumin-free. In the assessment of the date of healing these isolated abnormal specimens were ignored.

In Case 36 there were seven normal Addis counts, the first of which was two months after admission, and the last one year after admission, but albuminuria persisted for three years after the first normal count. Thereafter the urine was normal, so that the nephritis was regarded as healed 38 months after admission.

In Case 15 there were normal Addis counts two months and six months after admission, but there was a trace of albumin (15 mg. \%) in each 12-hour specimen. No more Addis counts were performed, and it was not possible to see the child again until almost a year after admission when the urine was found to be free of albumin. The time of healing was therefore recorded as one year.

In Case 17 the Addis count was normal 11 months after admission, but there was a trace of albumin (15 mg. \%) in the 12-hour specimen. Thereafter no further Addis counts were performed, and no urine was examined for a further period of six months. It was then normal, and the nephritis was regarded as healed.

Apart from these exceptions, the criteria for healing were rigidly applied.

\section{Comparability of the Two Groups}

In group $A$ there were 10 girls and 12 boys: in group $B$ there were nine girls and 11 boys. The average age in group A was 6 years 1 month (standard deviation 2 years 6 months); in group B it was 6 years 5 months (standard deviation 2 years 2 weeks). The average duration of symptoms before admission in group $A$ was $4 \cdot 7$ days and $4 \cdot 1$ days in group B. Seven children in group A and 11 children in group B had a systolic blood pressure on admission of over $120 \mathrm{~mm}$. $\mathrm{Hg} ; 13$ children in group $A$ and 15 children in group $B$ had a blood urea on admission of $40 \mathrm{mg}$. per $100 \mathrm{ml}$. or more. The average duration of observation in group A (excluding the child who died) was $30 \cdot 8$ months compared with 31.6 months in group $B$. It will be seen, therefore, that the two groups are statistically comparable.

\section{Results}

There was one death, an 11-year-old boy in the low-protein group. He had a typical acute nephritis, with no suggestion that he had had nephritis before. His condition rapidly deteriorated, and after seven days he was changed to a Borst diet but he died four months after admission. Thus 21 cases remained in this group for analysis.

The results in the remaining children are shown in Tables 2 and 3 . It will be seen that there was no significant difference between the two groups. By the time three months had elapsed after admission, 18 in each group had had an albumin-free specimen: 13 in group $A$ and 12 patients in group B had had a specimen of urine which was not only albumin free but had no excess of red cells. Within six months of admission eight in group $A$ and seven in group B had healed; and within a year 16 in group A and 15 in group B had healed. One further child in group $A$ healed and three further children in group B, so that 17 in group A had healed during the period of observation, leaving four who had evidence of persistent nephritis. Eighteen in group B healed, with two showing evidence of persistent activity. As the period of observation in the two groups was comparable (13 in group $A$ and 15 in group B were observed for over two years), this comparison is valid.

The course of the blood pressure and blood urea was not analysed, because of certain omissions in the records. Inspection of the figures, for what it is worth, does not show any difference in the rate of fall of the blood pressure and blood urea in the two groups.

\section{Discussion}

Our investigation failed to reveal any advantage in restricting protein in the diet of children suffering from acute nephritis. We can say with certainty that if there is any difference it must be a very slight one, which could only be revealed by studying a much larger number of cases. There was not even a suggestion that children on a low-protein diet fared better than those given a normal diet. Children do not like a low-protein diet, and it should not be used unless it presents definite advantages. The series included several children with a considerable degree of hypertension and with a high blood urea level, but it is possible that if we had had more severe cases it might have been possible to demonstrate some advantage in protein restriction in the acute stage. That, however, is pure conjecture. No child had complete anuria. We would certainly not give such a child a normal diet because of the complex bacterial disturbances which occur in such cases.

The experimental evidence, obtained from a study of animals with experimental nephritis, mostly produced by kidney poisons, may have little bearing on the nephritis of human beings. The aetiology of the nephritis is different, and as we have already 
TABLE 2

RESULTS

\begin{tabular}{|c|c|c|c|c|c|}
\hline Case No. & $\begin{array}{c}\text { Duration of } \\
\text { Observation } \\
\text { (Years and Months) }\end{array}$ & $\begin{array}{c}\text { Duration of Diet } \\
\text { (Days) }\end{array}$ & $\begin{array}{l}\text { First Albumin-free } \\
\text { Specimen of Urine } \\
\text { (Days after Admission) }\end{array}$ & $\begin{array}{l}\text { First Albumin-free } \\
\text { Urine without Excess of } \\
\text { R.B.C. on Microscopy } \\
\text { (Days after Admission) }\end{array}$ & $\begin{array}{c}\text { Healed }+ \\
\text { (Months after } \\
\text { Admission) }\end{array}$ \\
\hline $\begin{array}{c}\text { Group A: } \\
1 \\
2 \\
3 \\
4 \\
4 \\
5 \\
6 \\
7 \\
8 \\
9 \\
10 \\
11 \\
12 \\
13 \\
14 \\
15 \\
16 \\
17 \\
18 \\
19 \\
20 \\
21 \\
22\end{array}$ & $\begin{array}{c}\text {-Protein Diet } \\
4 \cdot 4 \\
3 \cdot 1 \\
3 \cdot 11 \\
1 \cdot 0 \\
3 \cdot 7 \\
1 \cdot 5 \\
1 \cdot 9 \\
2 \cdot 2 \\
2 \cdot 9 \\
3 \cdot 0 \\
2 \cdot 4 \\
1 \cdot 2 \\
1 \cdot 2 \\
3 \cdot 1 \\
3 \cdot 3 \\
3 \cdot 6 \\
1 \cdot 11 \\
1 \cdot 0 \\
4 \cdot 4 \\
\text { Died } \\
3 \cdot 2 \\
1 \cdot 11\end{array}$ & $\begin{array}{r}325 \\
202 \\
232 \\
181 \\
1,214 \\
143 \\
320 \\
434 \\
146 \\
227 \\
310 \\
429 \\
241 \\
242 \\
132 \\
353 \\
350 \\
64 \\
162 \\
7 * \\
191 \\
260\end{array}$ & $\begin{array}{l}84 \\
15 \\
28 \\
20 \\
\text { None } \\
28 \\
28 \\
90 \\
21 \\
56 \\
19 \\
\text { None } \\
13 \\
99 \\
14 \\
42 \\
301 \\
48 \\
77 \\
\text { None } \\
8 \\
6\end{array}$ & $\begin{array}{l}119 \\
49 \\
4 \\
21 \\
\text { None } \\
42 \\
154 \\
182 \\
42 \\
154 \\
19 \\
\text { None } \\
13 \\
99 \\
28 \\
49 \\
336 \\
56 \\
126 \\
\text { None } \\
22 \\
19\end{array}$ & $\begin{array}{c}10 \\
7 \\
3 \\
2 \cdot 5 \\
2 \cdot 5 \\
\text { Not } 40 \\
1 \cdot 5 \\
6 \\
\text { Not } 26 \\
1 \cdot 5 \\
4 \cdot 5 \\
10 \\
\text { Not } 14 \\
\text { Not } 14 \\
8 \\
6 \\
7 \\
10 \\
12 \\
16 \\
\text { Died } \\
3 \\
9\end{array}$ \\
\hline $\begin{array}{c}\text { Group B: } \\
23 \\
24 \\
25 \\
26 \\
27 \\
28 \\
29 \\
30 \\
31 \\
32 \\
33 \\
34 \\
35 \\
36 \\
37 \\
38 \\
39 \\
40 \\
41 \\
42\end{array}$ & $\begin{aligned} & \text { mal Diet } \\
& 3 \cdot 6 \\
& 1 \cdot 2 \\
& 4 \cdot 2 \\
& 1 \cdot 2 \\
& 3 \cdot 0 \\
& 1 \cdot 6 \\
& 2 \cdot 0 \\
& 3 \cdot 3 \\
& 3 \cdot 1 \\
& 2 \cdot 1 \\
& 4 \cdot 5 \\
& 3 \cdot 5 \\
& 1 \cdot 2 \\
& 3 \cdot 2 \\
& 1 \cdot 0 \\
& 2 \cdot 4 \\
& 3 \cdot 10 \\
& 2 \cdot 6 \\
& 3 \cdot 6 \\
& 2 \cdot 6\end{aligned}$ & $\begin{array}{l}= \\
= \\
= \\
= \\
= \\
= \\
= \\
= \\
= \\
=\end{array}$ & $\begin{array}{r}154 \\
13 \\
56 \\
42 \\
35 \\
18 \\
90 \\
23 \\
7 \\
70 \\
154 \\
23 \\
90 \\
45 \\
21 \\
29 \\
27 \\
8 \\
7 \\
90\end{array}$ & $\begin{array}{r}90 \\
210 \\
105 \\
42 \\
56 \\
21 \\
90 \\
35 \\
119 \\
105 \\
960 \\
42 \\
119 \\
1,080 \\
21 \\
182 \\
90 \\
42 \\
56 \\
90\end{array}$ & $\begin{array}{c}24 \\
\text { Not } 13 \\
7 \\
4 \\
3 \cdot 5 \\
5 \\
9 \\
7 \\
8 \\
7 \\
32 \\
2 \\
12 \\
38 \\
3 \\
\text { Not } 28 \\
10 \\
2 \cdot 5 \\
1 \cdot 5 \\
10\end{array}$ \\
\hline
\end{tabular}

- Transferred thereafter to Borst diet.

+ In the 'Healed' column, 'Not' with a figure after it, means that healing had not occurred during that period of observation. at the time of writing this paper.

TABLE 3

PROGRESS AND HEALING AT VARIOUS PERIODS AFTER ADMISSION

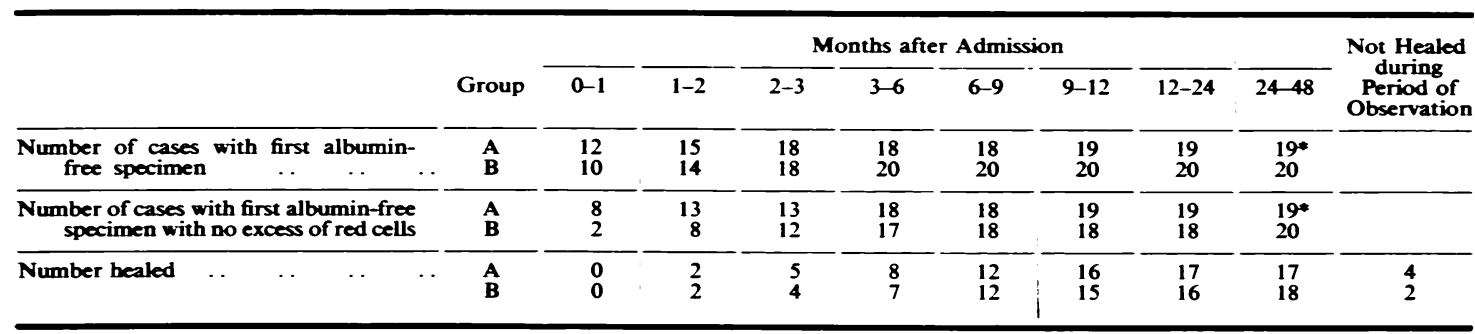

- Persistent albumin during period of observation in two cases.

+ Group A consisted of 22 patients on a low-protein diet but one died. Group B consisted of 20 patients on a normal protein diet. 
pointed out, the quantity of protein given to animals in the high-protein groups was far in excess of anything which is ever given to human beings. We feel now, in view of the strong evidence that a normal protein intake in acute nephritis in children is harmless, that the onus is on those who advocate severe protein restriction to provide evidence in support of their views.

\section{Summary}

Forty-two children aged from 2 to 14 years, suffering from acute nephritis, were allocated by the random sampling method to one of two dietary regimes, severe protein restriction and the normal ward diet. No case was observed for less than a year: the average period of observation was over two and a half years. The two groups were shown to be statistically comparable. Strict criteria for 'healing' were laid down.
There was one death in the low-protein group. In the remaining children no significant difference in the rate of healing was observed.

We concluded that we had been unable to demonstrate any advantage in protein restriction.

Our thanks are due to G. H. Jowett, B.A., Ph.D., and Miss Gibson, of the Department of Mathematics, the University of Sheffield, for statistical assistance, and to all the numerous house physicians and to the ward sisters, especially Sisters Jones, Isaac and Watson, for their cooperation and help in this study. We also wish to thank Miss E. Finch, M.Sc., Mrs. M. J. Walker, Ph.D., and Miss S. Stewart, B.Sc., for the laboratory investigations.

\section{Rermences}

Addis, T. (1940). J. Amer. diet. Ass., 16, 306.

Farr, (1948). Glomerular Nephritis. New York. 36,472 .

Mortensen, V. (1947). Acta med. scand., 129, 321.

Naeraa, A. (1938). Ibid., 95, 359.

Schwensen, C. (1935). Ugeskr. Laeg., 97, 793.

- (1937) Ibid 99, 627 